\title{
Çocukluk Dönemi Dini Inanç Gelişimi ve Din Eğitimi
}

\author{
MUSTAFA KÖYLÜ \\ DOC. DR, ONDOKUZ MAYIS Ü. ILAHIYAT FAKÜLTESI \\ e-mail:mkoylu@omuedu.tr
}

\begin{abstract}
The Development of Religious Belief and Religious Education of the Childhood Period. The religious development of childhood period is extremely important for a sound and healthy religious practices in the future of the person. How this period is important for the child from point of biological, psychological and social aspects, it is also important for his/her religious development and religious education, too. Then, in order to acquire an effective religious knowledge for the child, it is really important to know their religious development. In this context, this article examines first, the general religious characteristics of the childhood period, second, some factors affecting on religious education of the child, and third and lastly, the teaching methods of religious beliefs of the child.
\end{abstract}

key words

Child, Religious Development, Religious Education

\section{Giriş}

Çocukluk dönemi bireyin ileriki hayatının temellerini oluşturması ve karakterinin şekillendiği dönem olması açısından oldukça önemlidir. Birey kendisini yetişkin hayatına hazırlayıcı davranı̧̧lan büyük ölçüde küçük yaşlarda ögrenir ve bu öğrenmeler onda derin izler burakur. Hatta bazı psikologlar kişilik gelişiminin \% 90'ınin çocukluğun ilk 6 yllında gerçekleş̧tiğini ileri sürmektedirler. ${ }^{1}$ Bu durum da bize çocukluk dönemi eğitiminin asla ihmal edilmemesi gerektiğini göstermektedir.

Bireyin gençlik ve yetişkinlik dönemindeki dini inanç, duygu, tutum ve davranışlanın temeli de büyük ölçüde çocukluk döneminde atılmaktadır. Buna göre verilecek iyi bir eğitimle çocukta din duygusunun sağlıklı bir gelişimi sağlanabileceği gibi, yanlış ya da baskıcı bir eğitim vermek suretiyle

' Bkz. Doğan Cağlar, Uyuorsue Coodklar we Eğtioin, 2. Baskı AÜ.E.F. Yay., Ankara, 1981, 34; James Michael Lee, "Towand a New Era: A Blueprint for Positive Action," The Religias Education We Need, ed. James Michael Lee, Religious Education Press, Mishawaka, Ind., 1977, 115. 
ondaki din duygusunun körelmesine hatta dinden uzaklaşmasına neden olunabilir.

Çocuğa sağlkhı ve etkili bir din eğitimi verebilmek için, onun fiziksel, psiko-sosyal, duyuşsal ve zihinsel gelişim alanlannın yanunda, dini gelişim özelliklerinin de göz önüne alinması son derece önemlidir.

İşte bu makalenin amacı da, çocukluk dönemi dini inanç gelişimini bu alanda yapılan araştırmalar doğrultusunda ortaya koyarak, daha doğru ve sağlıklı bir din öğretimi ve öğretimi gerçekleştirmeye çalı̧̧maktır. Bu amaçla makale önce, a) ana hatlanyla çocukluk dönemi dininin özelliklerini, b) çocuğun dini eğitimine etki eden bazı faktörleri ve c) çocukluk dönemi inanç öğretimine ilişkin bazı temel ilkeleri ortaya koymaya çalışacaktır.

\section{A. Çocukluk Dönemi Dinin Genel Özellikleri}

Çocukluk döneminin en önemli özelliklerinden birisi, çocuğun "kolay inanurlık" özelliğine sahip olmasıdır. ${ }^{2}$ Çocuğun dine yabanculaşması ya da ona karşı ilgisizliği bir tarafa, o dine karşı oldukça hazır ve kabiliyetli bir durumdadır. Esasen çocuk düşünmeden, şüphelenmeden ve itiraz etmeden inanmaya hazır olduğundan, söylenenlere içtenlikle inanır. Çocuk sadece dış yönüyle değil, aynı zamanda ruhî olarak da samimî bir şekilde inanur. Çünkü çocuk, inanmakla kendisini güçlenmiş ve Allah'a yakın hissetmiş kabul eder. Böylece o, inandıllarıyla kendi kişisel dünyasını kurmaya ve onu geliştirmeye çalışır. ${ }^{3}$

Çocukluk dönemi dininin ikinci belirgin özelliği, ben menkezai bir yönelimli olmasıdır.4 Çocukluk dönemindeki bu ben merkezci yaklaşım sadece onun fizikî ve biyolojik ihtiyaçlanın karşlama noktasında olmayı, dinî inancında da kendisini göstermektedir. Bu özelliğin bir sonucu olarak, Allah çocuğun yaratıcısıdır, ona anne, baba ve kardeş vermiştir. Sonra yararlanması ve yaşaması için yiyecekler, içecekler, giyecekler vs. vermiştir. Kısacası $O$, kendisine gerekli olan her şeyi verdiği ve vereceği gibi, isteklerini ve dilediklerini geri çevirmemiş ve çevirmez de, yani Allah, çocukla birliktedir. Cocuk, Allah'ı kendisinden uzaklaştırmaz, Allah daima onun yanındadır. ${ }^{5}$ Çocuklann bu özelliği onlann dua anlayısına da yansımaktadır. Genellikle çocuklarn dualan da hep bu "ben merkezci" duygu ve düşüncelerle

2 Edwin D. Starbuck, The Psydbdogy of Religion, Walter Scott Pub., New York, 1908, s. 189.

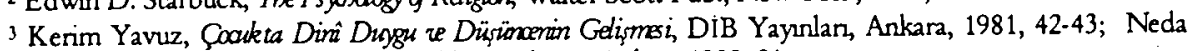
Amaner, Din Psikdoijisine Gini, Ayyldız Matbaasi, Ankara 1980, 81.

4 Rober W. Crapps, An Introduction to Psyohdogy of Religion, Merger Press, 1986, 168-169; Jean Piaget, The Moral Judgment of the Orild, Free Press, New York, 1965, 35-42.

5 Yavuz, a.ge, 174. 
doludur.6 Dolayssıla bu dönemde çocuklardan herhangi bir özgeci davranısın beklenmesi gereksizdir.

Çocukluk dönemi dininin üçüncü özelliği, antropomonfik bir özellik taşımasıdır. Çocukluk dönemi dini inançlanna ilişkin yapılan araştırmalarda, onlann genellikle somut bir Allah tasavvuruna sahip olduklan görülmektedir? Buna göre Allah, yaşh, olgun ve erkek, yani insanî özellikler taşıyan bir varlık olarak tasavvur edilmektedir. Allah tasavvurunun böyle özellikler göstermesi, çocuklann yaşlan küçüldükçe daha belingin bir niteliks kazanmaktadır. Ancak batı Hıristiyan kültüründeki çocuklar, Allah'ı birtakım insanî özelliklerle düşünseler bile, yine o siradan bir insan olmayp, birtakım üstün özelikleri olan bir varlkktır. Genellikle $\mathrm{O}$, baba veya büyük baba ya da sakall Santa Claus 8 olarak düşünülïr ve tasavvur edilir. Onun görecek gözleri, tutacak elleri ve konuşacak bir dili vardır. ${ }^{9}$

Böyle bir inancın oluşmasında çocukların yaşadığı dinî kültürün de önemli bir faktör olduğunu belirtmek gerekir. Her ne kadar ülkemizde yapılan araştırmalarda da, özellikle yaşlan küçük olan bazı çocuklann Allah’ı insana benzeyen bir varlık olarak tasavvur ettikleri görülse de, bunu çocuk isteyerek değil, suff anlama kapasitesinin ötesinde olduğu ve Allah'ı gerçek anlamda tarif edemediğinden böyle davrandı̆̆ belirtilmektedir.10 $\mathrm{Bu}$ tür eğilim içinde olan çocuklar, Allah'ı daha çok "ulu kişi," ve "yüce kişi”" olarak düşündüklerini söylemektedirler. Bu arada O’nu bir objeye benzetmekte güçlük ve kararsızlık çekenlere de rastlanmaktadır. Örneğin bu dönemdeki çocuklar (7-9 yaş) “Allah'1 Allah zannediyorum. O'nu korkunç bir şey sanyorum. Bilmem. Allah insana benzer ama Allah ölmez. Allah'a insan

\footnotetext{
${ }^{6}$ Örnek olarak bkz. David J. Ludwig ve Arkadaşlan, “Letters to God: A Study of Children's Religious Concepts," Jamnal of Psyobology and Theology, Vol 2, no. 1, 1974, 31-35; Diane Long ve Arkadaşlan, "The Child's Conception of Prayer," Joumal for the Scientific Stuty of Religion vol 6, no. 1, 1967, 102-109;

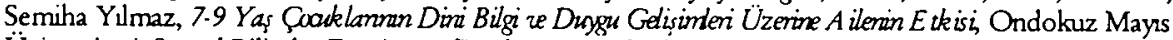
Üniversitesi, Sosyal Bilimler Enstitüsü, (Basimamş̧ Yüksek Lisans Tezi) Samsun 1999, s. 84.

7 Ömek olarak bkz. Kalevi Tamminen, Renzo Vianello, Jean-Marie Jaspard, Donald Ratcliff, "The Religious Concepts of Preschoolers," Handbook of Preshod Religious Edrecation ed. Donald Ratcliff, Religious Education Press, Birmingham, Alabama, 1988, 59-81; Renzo Vianello, Kalevi Tamminen, ve Donald Ratcliff, "The Religious Concepts of Children," Handbook of Orildren's Religious Education ed. Donald Ratcliff, Religious Educatioǹ Press, Birmingham, Alabama, 1992, 56-81; Kenneth E. Hyde, Religion in Orildbood and Addescence, Religious Education Press, Bimningham, Alabama, 1990; Hayati Hökelekli, Din Psikdö̈si, Türkiye Diyanet Vakf, Yay., Ankara, 2001, 264265.

8 Santa Claus Efsanevi Myra piskoposu Aziz Nicholas'in isminin Almanca şeklinin Amerika'daki yaygın kullanuşıdır. 6 Aralık günü çocuklara hediyeler getirdiğine inanılan, çocuklann, denizcilerin ve Rusya'nun konuyucu azizi olarak kabul edilir. Bkz. Şinasi Gündüz, Din ze Inaņ̧ Sözlüğ̈̌̆, Vadi Yaynlan, Ankara, 1998, 284, 332.

${ }^{9}$ Crapps, a.ge, 170-171.

10 Yavuz, ag.e, 174 vd; Hökelekli, agge, 262-263.
} 
desem olmaz. O'nu büyük bir insan zannediyorum. O'nun nasıl olduğunu hâlâ merak ediyorum," gibi anlatımlar, çocuklann bu konudaki karmaşalannı ve eğilimlerini açıkça ortaya koymaktadır. Dolaysıyla burada çocuklann böyle antropomonfik bir düşünce tarzına sahip olmalannda, onların henüz yeterli bir düşünce düzeyine sahip olamamalan kadar, yaşadıklan aile ortamı ve çevrenin de önemli derecede etkili olduğunu söyleyebiliriz. ${ }^{11}$

Çocukluk dönemi dininin dördüncü temel özelliği, tecrübe, teşebbüs ve kendiliğinden ortaya çıkan spontane bir dinî tecrübeye dayalı olmasıdır. Çocuğun dünyası hızla genişledikçe, aile çevresinin ötesinde yeni yüzler ortaya çıkar. Bu yüzden çocukluk döneminde dört, beş ve altı yaşlar son derece önemlidir. Zira bu dönemde çocuklar, ailelerinin ötesinde arkadaşlan ve akranlanyla tanışır ve sosyal bir çevre oluștururlar. Kişilik gelişimleriyle ilgili anaokullan veya kreşler, onlar için yeni bir dünya oluşturur. Yine bu dönemde çocuğun sadece çevresi genişlemez, kendisi de deneme ve yanulma yoluyla pek çok şeyi tecrübe eder ve öğrenir.12

Özetle, dinî gelişim açısından çocukluk dönemi dinamik bir zaman dilimidir. Çocuklann inanılmaz derecede yetişkinleri taklit etme kabiliyetleri vardır ve bu açıdan başta ebeveyn ve diğer aile büyükleri olmak üzere, dinî kurumlar taklit için uygun modeller oluşturabilir. ${ }^{13}$ Elbette çocuğun yetişkinleri taklit etmesi önemlidir, ancak bundan daha da önemlisi, çocuğun kendi dinî tecrübe ve yaşantısıdır.

\section{B. Çocuğun Dini Eğitimine Etki Eden Bazı Faktörler}

Yas faktörü: Cocuklann dini düsüunce ve Allah tasavvurlannun oluşmasındaki en önemli faktörlerin başında yaş faktörü gelmektedir. Küçük çocuklar yetiştikleri çevre ve ortama bağl olarak bir Allah tasavvuru ve dini inanç şekli geliştirebilirler. Ancak onlann sahip olduklan inanç hakkında çok detayłı fikirleri yoktur. Örneğin beş yaşındaki bir çocuk kendi inandı̆ı bir Allah inancıyla diğer din mensuplannun inandığı Tann fikri hakkında henüz bir aynm yapamaz. Belki aile ya da çevresinde çok bilinçli bir eğitim almanun dışında, küçük çocuklar için bu gibi dini konulardaki bilişsel sınılamalar önemli rol oynarlar. Ancak bununla beraber eğer bir genelleme yoluna gidilirse, küçük çocuklann olumlu ve llmb bir Allah anlayışına sahip

${ }^{11} \mathrm{Bkz}$. Vianello ve Arkadaşlan, a.g.b., (adı geçen bölüm), 57-59; 62-64; Yavuz, a.ge, 159-162.

12 Crapps, age, 172-173.

13 Bkz. Hüscyin Peker, Din we Ablak Eg̈itim: Psikdoijk ze Metodik Esaslar, Samsun 1998, 48-51; Yavuz, a.ge, 146-152. 
olduklan söylenebilir.14 Genellikle eğlence ve oyunla ilişkilendirilecek bir Allah anlayısı sergilerler. Allah, basit ve dünyevi zevklerle ilintili olup, genellikle çocukların hayallerine cevap veren bir varlık olarak kabul edilir. ${ }^{15}$

Meseleye yaşlar açısından bakıldığında, 4-6 yaş grubundaki çocuklarnn Allah anlayışıun açık bir şekilde bireysel ilgi üzerine temellendiği görülmektedir. Bu zati odaklanma, onlarn kesinlikle Allah anlayş̧lann ve düşüncelerini de etkilemektedir. Dolayssıyla küçük çocuklar için farklı Allah tasavvurlan vardır ve hepsi de onun iyiliği ve istekleri için çalışmaktadır. Ömeğin beş yaşındaki bir çocuğa, Allah'in varlğına ilişkin delil konusunda ne düşündüğü sorulduğunda, cevabı "Allah beni yaratı" olacaktır. Meseleye psikoanalitik açıdan baktı̆ı̆ızda, bunun biraz da çocukluk döneminin özelliğinin kendisine fazla önem vermesi ve ben merkezci (egosentrik) bir anlayışa sahip olmasından kaynaklandığı sonucuna varabiliriz. ${ }^{16}$

7-9 yaş grubundaki çocuklar, 4-6 yaş grubunun aksine, resmi bir Allah kavramı hakkındaki büyüyen meraklan kadar, dini uygulama ve figürler konusunda da artan bir farklllkk gösterirler. Onlarn bu gelișen ve büyüyen ilgileri ve araştıncı ruhlan, onlann bireysel anlamdaki mücadele ve meraklarından kaynaklanmaktadır. Elbette bu her çocuk için aynu anda gelişir demek, ya da tüm çocukların aynı merak ve ilgiyi gösterecekleri anlamına gelmez. Her ne kadar çocuklann gelişimsel olarak, bilişimsel kapasiteleri önemli bir rol oynasa bile, onlarn merak ve olaylarn farkındaluğı onlann kendi sosyalleşme tecrübelerine bağhldır. Dolayısıyla bu dönemdeki çocuklarnn dinle ilgili sorulan, dualan ve pratikleri ne tamamen ögrenmeye bağh, ne de tamamen fitrî olup, aksine onların hayat tecrübelerinden kaynaklanmaktadir. ${ }^{17}$

$\mathrm{Bu}$ dönem çocuklannın Allah anlaysşlan ve özeliklerini yakından incelediğimizde şu sonuçlara varabiliriz: Her şeyden önce bu dönem çocukları kendilerinin çok özel olduğu konusunda müthiş bir arzulan olup, Allah'n gözünde de özel bir varllk olarak görülmeyi isterler. Bu dönem çocuklannda bireysel önembilik sevilme ihtiyacın da aşarak, diğerlerinin ötesinde bir takdir edilme duygusunu geliştirir. Bunun temel nedeni de en azından bazı çocuklar için aileye yeni çocuklarn katılması ve büyük çocuklara karşı olan ilginin azalması ve büyük çocuğun tekrar bu ilgiyi elde etmeye

\footnotetext{
14 Ömek olarak blkz. Yurdagül Konuk, Okul Önesi Çocuklanda Dirn Dongınan Geli̧̧im ue Eg̈itim, Diyanet Vakf, Yay., Ankara, 1994, 76-77;

15 Ömeğin 7.9 yaş grubu çocuklara "Allah'in dualannuzı kabul ettiğine inanyor musunuz?" sorusuna, \% 94 'ü "Evet, Allah dualan kabul edicidir," diye cevap vermişlerdir. Bkz. Yllmaz, ag t., s. 84.

${ }^{16}$ David Heller, The Children's God, University of Chicago Press, Chicago and London, 1988, 39-44.

${ }^{17}$ Socuklann bu tür özellikleri için blkz. Yavuz, age, 220-234.
} 
çalışmasıdır. Artık büyïk çocuk ailenin temel ilgi alanı değildir. Artık eskisi gibi, her hareketi anne ve baba tarafından izlenmemektedir. İşte böyle bir ortamda çocuk, kaybolmuş olan bu özelliğini ailesinden beklemek yerine, Allah'ta aramaktadır. ${ }^{18}$

10-12 yaş grubuna gelince, bu dönem çocuklannın en büyük özelliği, çocukluk dönemine ait çocuksu bir Allah anlayışııı yavaş yavaş terk ederek, olgun bir kişinin sahip olduğu Allah anlaysşına doğru yönelmesidir. Çocuğun böyle bir düşünceye ve inanca sahip olmasının nedeni de, çocuklann inancına göre önceki sahip olduğu Allah inancının kendisini tatmin etmemesidir. Böylece çocuk önceki sahip olduğu Allah inancını yeniden gözden geçirmeye ve şekillendirmeye çalş̧maktadır. Çocuk artık başkalannın yaşantılanına inanmaz, zira o kendine ait oluşturduğu inançlann yaşamaya başlar. Onun dua hakkındaki görüşleri de değişir. Çocuk büyüdükçe her duasının kabul edilmediğini gördükçe, duay artık alıştığı için ya da kendisinden beklendiği için yapar. ${ }^{19}$ Bu yaş grubunun diğer önemli bir yanı $\mathrm{da}$, onlann bu dönemde çeşitli şekillerdeki acı ve yaralanmalardan korkmalandır. Bunun da nedeni muhtemelen çocuklarun eskisi kadar anne ve babalan tarafından korunmamasıdır. Bu acı motifinin bir izahı da artık çocukların ben merkezcilikten uzaklaşmalandır. Artık onlar her şeyin iyi gitmediğini, dünyada acı ve ızdırabın, zarar ve ziyanın da gerçek olduğunu görmüş olmalandır. İşte tüm bu gelişmeler sonucu çocuklar bir taraftan güçlü bir inanç ve kanaate sahip olurlarken, diğer taraftan bazı şüphe ve tereddütlere de düşebilirler..$^{20}$

Böyle bir ortamda çocuğun hayatında Allah'ın yeri ve rolü nedir? Bu durum çocuklar için çok açık ve net değildir. Her ne kadar onlar Allah'in rahmetinden, şefkatinden ve affetmesinden bahsetseler bile, yine de onlann belirsizliği aşikar olup temel olarak şu iki soruyu sormaktadırlar: 1) Bu acı ve ızdırap dolu dünyada Allah'n rolü nedir? 2) Allah niçin insanların bu acı ve ızdırap içinde yaşamalanna izin vermektedir?21 Çocuklar her ne kadar bu sorulan açıkça sormasalar da, bu soruların cevabını tatmin edici bir şekilde

\footnotetext{
${ }^{18}$ Heller, The Orildren's God, s. 46.

19 Belma Özbaydar, Din ze Tann Inanaran Gelismesi Üzerine Bir A rasttrma, Baha Matbaası, İstanbul, 1970, 13.

20 Yavuz, a.ge, 230-240; Özbaydar, age, 13.

${ }_{21}$ Aslinda bir bakıma "kötülük problemi" olarak da adlandırabileceğimiz bu durumun, sadece 10-12 yas grubu çocuklara ait olmayp, daha erken dönemlerde de ortaya çlkruğı görülmekedir. Ömeğin 5-6 yaşındaki çocuklar, özellikle belgeselleri izlerken, avlanan küşük savunmasız yavrulan ya da güçsüz hayvanlann öldürülmesini sik sik sorarak, niçin, Allah'in böyle bir șeye müsaade ettiğini sormaktadirlar. Cocukluk dönemi kötülük problemi için bkz. Randolph C. Miller, "The Problem of Evil and Religious Education," Religions Education vol 84, no 1, 1989, 5-15.
} 
bilmedikleri de bir gerçektir. Tabi bu acı ve ızdırabın çocuklan Allah hakkında bir takım şüphe ya da olumsuz bir imaja sahip olmalarına neden olabileceği gibi, Allah'a daha çok yaklaşmalanna da neden olabilir. ${ }^{22}$

10-12 yaş arasındaki çocuklar Allah'in gücü, kudreti ve sınurlukklan hakkında oldukça meraklıdırlar. Allah'ın gücü ile ilgili olarak, onun neleri yapıp neleri yapamayacağı konusunda onun gücünü öğrenmek isterler. Aslında onlann Allah'in gücünü ya da sınınn merak etmelerinin nedeni, onların kendi sınurlulkklanı yansıtmaktadır. Zira onlar büyüdükçe, her şeyi yapamayacaklannı öğrenirler. Bu durum çocuklann en zorlandıklan bir durum haline gelir. İşte kişilik krizlerinin her bir safhası, çocuklanın dini kavramlan yeniden değerlendirmeye ve yeniden tasdik etmeye götürür. ${ }^{23}$

Cinsinet faktörï: $\mathrm{K} ı$ ve erkeklerin Allah hakkındaki tasavvurlan da farklllik göstermektedir. Araştırmalara göre, erkek çocuklannın Allah anlayş̧lan daha rasyonel bir özellik göstermektedir. ${ }^{24} \mathrm{Bu}$ durum onlann Allah'ın nerede olduğundan, eylemlerine kadar her alanda kendisini göstermektedir. Örneğin on yaşındaki bir çocuk, Scott, Allah'in nerede yaşadığını şu ifadelerle dile getirmektedir: "O bir gezegende yașamaktadır. Bu yüzden O'nu görmek için özel gözlüklere ihtiyaç vardır. O'nu görmek için önce güneşi geçmek, ondan sonra gezegenlere, ondan sonra galaksiye ulaşırsın... Sadece bundan sonra ve yalnızca bundan sonra O'nu bulabilirsin..."25 Erkek çocuklan Allah'ı sadece böyle astronomi yönlï izah etmekle kalmazlar, aynu zamanda onun insan hayatında sürekli olarak aktif olmasın isterler. Dolayssıyla erkek çocuklann gözünde arzulanan her hangi bir hedefe ulaşmada Allah'in planı ve onay gereklidir. Allah'in belli bir yerde oturması ya da pasif bir konumda olması yerine o, sürekli olarak bir şeyler yapmaktadır. Bundan dolayı o insanlann gücünü aşar. ${ }^{26}$

Erkek çocuklann inandığı Allah'ın bir diğer özelliği de, onun oldukça uzak bir yerde olduğu şeklindeki inançlandır. Heller'in araştırmasına göre, Allah sadece coğrafik olarak uzak olmayı, ayn zamanda çocuğun günlük yaşamına müdahil olsa da, duygusal ve hissi olarak da uzaktır. Örneğin 6 yaşındaki bir çocuk Allah'ı, insanlardan uzak bir çölde yaşadığını hayal ederken, 12 yaşındaki bir çocuk da O'nun görünmediğini ve O'na ulaşmanun çok zor olduğunu ifade etmiştir. Aslında çocuklar Allah'in ne kadar uzak

\footnotetext{
${ }^{22}$ Heller, The Crildren's God, 47-53.

${ }^{23}$ Heller, The Childon's God, 53.

24 Özbaydar, a.ge, 43.

${ }^{25}$ Heller, The Crildren's God 58.

${ }^{26}$ Heller, The Orildren's God, 59.
} 
mesafede olursa olsun, kendilerini yardıma muhtaç ve aciz hissettiklerinden, insanlara ve kendilerine yardımcı olduğunu ve kendilerine daha yakın olmasın istemektedirler.

Erkek çocuklanın Allah'ın kadın olması hakkında da bir kayglan vardır. Yaşlan ne olursa olsun tüm çocuklar, Allah'ın kadın değil, erkek olması gerektiğini ve erkek olduğu fikrini paylaşırlar. Hatta Heller, dokuz yaşındaki bir çocuğa Allah'in cinsiyetini sorduğunda, "tabi ki o erkektir. Hatta onun bir kadın olmasını hayal bile edemiyorum," diye cevap vermiştir. ${ }^{27}$

Erkek çocuklar Allah'ı bu şekilde tasavvur ederlerken, kız çocuklan Allah'ı biraz daha değişik açıdan tasavvur etmektedirler. Kız çocuklan Allah'ı daha estetik ve daha artistik bir dünyaya müdahil olan bir varlik olarak görmektedirler. Genel olarak kuzlarnn dünyasinda Allah, erkeklerin dünyasında olduğu gibi, çok fazla somut gerçeklerle ve olaylarla ele alınmamaktadır. Onlann tasavvurlannda, Allah sese ve renge, tabiat ve tabiat fenomenlerine daha yakınken, teknik ve bilimsel yaplardan daha uzaktır. Onlann bazen estetik ve cinsel niteliklerini Allah anlayışlanna da yansıttıklan görülmektedir. ${ }^{28}$

Kızlann Allah'la ilgili olarak bir başka düşünceleri de, Allah'in daha pasif, ya da insanlanı Allah'la olan ilişkilerinin sıradan olduğuna ilişskin düşünceleridir. Allah'ın aktifliği onlann temel ilgi alanı değildir. Genellikle kuzlarla Allah arasındaki "alma ve verme" ilişkisi daha doğrudan ve daha aşikardır. Allah kız çocuklann hayatlann, kendi sessiz tefekkürleri ve yaratıcı gayretlerinden dolayı etkilemektedir. Kızlar için Allah daha az agresif ve hal ve hareketlerde daha aşikardur. Ancak iletişim konusunda hiç de daha az müdahale edici veya daha az önemli değildir.

Kızlann Allah anlayşlannın bir diğer özelliği de, erkeklerle kıyasladığımızda, mesafe olarak daha yakın bir Allah anlayışına sahip olmalandır. Allah'a en azından duygusal bir yakınlik duyarlar. Ara sıra kuzlar Allah'la fiziki bir yakınlığa vurgu yapsalar bile, çoğunlukla onlar Allah ile insanlar arasındaki duygu değişimini tercih ederler. Kız çocuklarn Allah'ı sadece sözel olarak tasvir ettiklerinde değil, aynı zamanda onu resmettiklerinde de onu gülen ve sempatik bir varlık olarak tasvir etmişlerdir. ${ }^{29}$

\footnotetext{
27 Heller, The Orildren's God, 65.

28 Yavuz, agge, 97; Bu konuda erkek ve kadınlar arasındaki farklulklar için bkz. Mustafa Köylü, Psiko Sasyal A gadan Divi İletisim Ankara Okulu Yay., Ankara, 2003, 70.75.

${ }^{29}$ Bkz. Heller, The Orildon's God, 70.
} 
Kişilik äzellikleri: Çocuklann yaşlan ve cinsiyetleri kadar kişilik yapılan da onların Allah hakkındaki düşüncelerini etkilemektedir. Bunun aile yapısıyla, anne ve babanun çocuğa karşı ilgi ve davranıslanyla yakından ilgili olduğu görüilmektedir. Çocuklarnn Allah inancına ilişkin derinlemesine yaptığ araşturmada, Heller, çocukların yetiştikleri aile ortamına bağh olarak 6 tür Allah inancına sahip olduklarını belirtmektedir. Bunlan şu şekilde özetleyebiliriz.

Çocuklar arasında hakim olan birinci tür Allah anlayısı, onlann Allah'ı arkadaş̧̧a ve dostça bir varlık olarak kabul etmeleridir. Çocuklar arasında en hakim ve açıkça görülebilen bir Allah tasviri olarak, onun arkadaş ve dostça olma özelliği ortaya çıkmaktadır. Bu tür tasvirde, Allah çocuklann bir arkadaşı, akranı ve onlann oyunlannda ve aktiviteleninde bir arkadaş olarak rol oynar. Allah, çocuğun gözünde hayali bir oyun arkadaşı gibidir ve çocukla Allah arasındaki iliski kalbî ve hoşnut verici bir ilişkidir. Bu tarz bir düşünceye sahip olan çocuklar genellikle çok fazla dünya işlerine ve dünya olaylanna ilgi duymaz ve olumsuz duygu ve düşüncelerden kaçınurlar. Bu tür bir kişilik yapısına sahip olan çocuklar komik ve hoş sorulara cevap vermeyi yeğlerken, ölümle ilgili sonulara çok az ilgi gösterir. Bu tür olumlu yaklaşan çocuklar Allah'ı resimlediklerinde de ayn özelikleri göstermişlerdir. Bu tür ifadelere yer veren çocuklarn özelliklerine baktı̆̆ımızda, onlann hayatında sevgi konusunda bir eksikliğin olduğunu, dolaysılyla böyle bir inançla onu doldurmaya çahștiklannı ve bunun sonucu olarak, böyle bir Allah tasvirine yöneldikleri görülmektedir.

Ikinci bir Allah inancı şekli olarak, çocuklann öncekilerin tam aksine, kuzgın ve cani bir Allah tasviri ve inancına sahip olmalandır. Bu çocuklarnn tasvirine göre Allah, günlük yaşamı tayin eden Yaratıcıdan çok daha büyük olup, özellikle kızdı̆ı zaman kızgınlğının kontrol edilemediği bir Allah'tr. Bazen bu Allah sadist bir şekilde davranur ve eylemlerinde sevgi ve şefkatten uzak, keyfine göre hareket eder. Bu tür inanca sahip olan küçük çocuklar ya böyle bir Allah'tan korkarlar ya da bu kötü niyetli güçlü Allah'a alşarak büyümek isterler.

Resmi dinin dilinde bu kızgn Allah, adalet ve barıș Allah'ı yerine, gerçekten şimşeklerin, furtınaların, sel ve felaketlerin Allah'idır. Çoğunlukla savaşla ilişkilendirilen bu Allah, insanlar arasindaki gerginliklere ve düsmanlkklara müdahil olmaktadır. Bu tür inanca sahip olan çocuklarnn anne ve babalannun tutum ve dàranışlan incelendiğinde, genelde bu tür çocukların şiddet yanlısı, tek yönlü (one-sided) anne ve babalardan geldikleri görülmektedir. Sonuç olarak bu tür ailelerde yetişen çocuklar, yaşadıklan ve 
tecrübe ettikleri bu olaylan kendi Allah inançlanna da yansıtmaktadırlar. Yine yapılan araştırmalarda aile bireyleri arasındaki gerginlik ve kırgınlikların da bu tür bir Allah anlayışında oldukça etkileyici olduğu görülmektedir.

Çocuklar arasında hakim olan üçüncü tür bir Allah anlayışı da gökyüzünde, uzak bir yerdeki Allah portresidir. Bu tür Allah anlayışına sahip olan çocuklara göre, Allah müphem bir varlık olarak, kalabalıklardan uzak olup, çocuğun günlük ihtiyaçlanı karşlamaktan da oldukça uzaktır. Mesafe ve uzakluk bu Allah için zorunlu bir şeydir. Çocuklar bazen bu Allah'a ulaşmak isterler, ancak ona ulaşmanun imkansız olduğunu düşünerek vazgeçerler.

$\mathrm{Bu}$ tür inanca sahip olan çocuklann hiksayeleri, kendileriyle yapılan mülakatlar ve oyun sahneleri incelendiğinde, bu çocuklarnn müthiş derecede yaşadıklan ailelerde, kişiler arası, eşler arası ya da çocukla anne ve baba arasında bir ilişkisel uzaklığın olduğu görülmüştür. Yine çocukları böyle bir Allah anlayışına iten nedenlerden bir tanesi de onlanı yalnızlı̆̆ıdır. Dolayısıyla çocuklann bu iç, derûnî yalnuzhklan onların Allah anlayışıı da yansitmaktadır.

Dördüncü bir Allah tasviri de çocuklann tutarsız bir Allah anlayışına sahip olmalandır. Çocuklann önemli bir kısmı da iki yönlü hayalperest bir Allah inancina sahiptirler. Çocuklar bazı durumlarda olumlu bir Allah imajina sahipken, bazı durumlarda da büyük tutarsızlklara neden olabilecek bir Allah anlaysșına ve özelliklerine sahip olabilmektedirler. Bunun da nedeni, muhtemelen çocuğun gözünde iyi ile kötünün sürekli değişkenlik arz etmesi ve çocuğun hayatın tutarsızlıkların anlamada zorlanmasıdır. Bu duruma da yine büyük ölçüde çocuklann sahip olduğu aileler neden olmaktadır. Mülakat esnasında bu tür inanca sahip olan çocukların ebeveynlerinin de tutarlı olmadığı, bazen çocuğun yanında, bazen karşısında; bazen mükafatlandıncı bazen de hiç umulmadık bir şekilde cezalandınıcı bir ebeveyne sahip olduklan görülmüştür. Tabi böyle bir aile yaşantısına sahip olan çocukların Allah hakkındaki tasavvurlan da açık olmayacaktır.

Beşinci bir Allah tasavvuru şekli de, onun bir kral olarak tasvir edilmesidir. Kral rolünde olan Allah, yeryüzündeki insanlar için kanunlar koyar ve onlara adalet dağıır. Bu tür inanca sahip olan çocuklara göre, her ne kadar Allah sınursı bir güce sahip olsa bile, yine o gücünü yerli yerinde ve merhametli olarak kullanur. Bu bağlamda Allah, tam anlamula bir süpermendir. Ancak o sadece salt anlamda bir kahraman olmayp, evrensel gücü, merhametle ve şefkatle kullanan bir Allah'tur. Bu son derece güçlü olan Allah, ne tamamen sevecen bir karaktere, ne de tamamen bir öç alıcı ve kine 
sahiptir. Bununla beraber o tartışmasız şekilde hakimiyet sahibi olup, sıklıkla erkek karakteri şeklinde tasvir edilmektedir. Onun eylemleriyle ilgili olarak, o dünya işlerini organize eden ve düzenleyen bir varlıktır.

Çocuklan bu tür inanca sevk eden yine büyük ölçüde aile bireylerinin tutumlandır. Gerçekte bu çocukların ebeveynleri, her ne kadar otoriter ve diktatör olmasa bile, özellikle de babalan, göze çarpacak derecede kontrolcü ve güçlüdür.

Altıncı ve son olarak, bazı çocuklar için de Allah adeta bir terapist niteliğindedir. Bu tür düşüncelere sahip olan çocuklann gözünde Allah, şifa verici ve iyileştirici bir rol oynamaktadır. Böyle bir Allah tüm yiyecek ve içecekleri veren, seven ve koruyan, aile ve dünyadaki tüm yanlışlıklar üzerine hakkı olan bir varlıktır. Allah çocuklar için her şeyi onaylar ve bazen de bunu mucizevî bir şekilde yapar. Bu tür Allah'in temel özelliği, çocuğun hayatı, aile ilişkileri ve insanlar arası iliş̧kileri iyileştirici bir role sahip olmasıdır. Yine her türlü hastalıklan ve yaralanmalan da $\mathrm{O}$ tedavi eder.

$\mathrm{Bu}$ tür bir Allah anlayışına sahip olan çocuklanın ailelerine baktığımızda, onlarn çoğunlukla terapötik bir aile ortamından geldikleri görülmektedir. Elbette bu tür ailelerde de bazı olumsuzluklar olabilir. Ancak onlar bu tür olumsuzluklarla başa çıkma kapasitesine sahiptirler. Yine bu tür ailelerinin diğer bir özeliği de, otoriter ve katı disiplin anlayışına sahip olan anne ve babalardan ziyade, çocuklanna ihtimam gösteren aile ortamından gelmiş olmalandır. ${ }^{30}$

Aslına bakulirsa bu tür Allah inanç ve tasavvurlan çocukluk dönemiyle sınırlı olmayıp, insan hayatının daha sonraki dönemlerinde de kendisini hissettirmektedir. ${ }^{31}$ Burada önemli olan herhalde olumsuz özellikler yerine, olumlu özelliklere sahip bir Allah inancının verilmeye çalışlmasıdır.

\section{C. Çocuğa Allah Inancının Öğretimi}

Din eğitimcileri çocuklara ögrretilecek en temel ve en önemli şeyin Allah inancı olduğunu ileri sürmektedirler. ${ }^{32}$ Zira Allah inancı, diğer dini inanç ve uygulamaların da temelini oluşturmaktadır. $O$ halde çocuklara, dinî inancin da temelini oluşturan doğru bir Allah kavramını nasıl öğretmeliyiz? Her

\footnotetext{
${ }^{30}$ Heller, The Orildren's God, 79-93.

31 Yetişkinlendeki bu tür Allah inancs için bkz. Raymond G. Kuhlen, "Trends in Religious Behavior During the Adult Years," Wider Horizons in Constian A dult Education, ed. Lawrence C. Little, University of Pittsburgh Press, 1962, 1-25; James W. Fowler, Stage of Faith: The Psjobdogy and Human Dezelopment and the Quest for Meaning Harper and Row, New York, 1981, 122-211.

32 E. Paul Torrance ve J. Pansy Torrance, "Creativity and Teaching Concepts of God," Handbook of Preschod Religiass Education, ed. Donald Ratcliff, Religious Education Press, Birmingham, Alabama, 1988, 233.
} 
şeyden önce şunu kabul etmek gerekir ki, çocuklarla Allah hakkunda konuşmak ve onlann Allah hakkında sorduklan sorulan cevaplandırmak pek kolay bir iş değildir. Bunun birtakım nedenleri vardır. Önce bu nedenleri bilip, ona göre hareket etmek gerekir. Bunlan şu şekilde sıralayabiliriz.

Birinci olarak Allah, soyut bir kavramdır. Yani çocuklann günlük yaşamlarında karşılaştıklan somut bir varlık değildir. Bunun da ötesinde, O'nun her şeyi görmesi, her şeyi duyması ve her şeyi yapabilmesi, şeklindeki sıfatlannın çocukların anlayış seviyelerinin çok ötesinde olmasıdır. Ömeğin, "biz O'nu göremeyiz, fakat $O$ her şeyi görür. Biz hiçbir şeyi bilemeyiz, ama O kalbimizden geçen şeyleri bile bilir," gibi açıklamalan duyan 4-5 yaşındaki çocuklar, Allah ile ilgili olarak, son derece karmaşık ve zor sorular sorarlar. Örneğin, her çocuğun annesi ve babası olduğuna göre, Allah'in da annesi ve babası var mıdır, varsa onlar kimdir? Çocuklan var mıdır? Eğer dünyayı ya da bizi Allah yarattısa, O'nu kim yaratt? Allah nasil oldu? O erkek mi, yoksa kadın midır? Allah nerede yaşamaktadır? O'nun evi nerededir? Allah nasl her zaman yanımizda oluyor? Allah'a ulaşmak için ne kadar uzunlukta bir merdivene ihtiyaç vardır? Yağmur ve kar nasıl yağmaktadır? Allah niçin benim sevdiğim kedimi, o kazada öldürdü? Allah günahı olanı Cehenneme atar ve cezalandınr, kafama takılan şu: Allah acımasız mı? Insanlar Allah'a inanmasa ne olur? Insanlar dua ettiklerinde Allah onlann duasını işitir mi? Eğer Allah her şeyi görebiliyorsa, biz neden O'nu ya da her şeyi göremiyoruz? Eğer O her şeyi yapabiliyorsa, bana niçin bu kötü şeyi yaptırdı? Allah niçin savaş ve çatışmalanın çıkmasına izin veriyor? vs. ${ }^{33}$

Çocuklara Allah kavramım öğretmenin zor olmasının nedenlerinden ikincisi de, değişen toplum yapısıdır. Geçmişte Allah kavramı soyut tarzda değil, oldukç̧a canl ve somut bir şekilde insanlarn düşünce ve inanç dünyasina aktanliyordu. Olan ya da meydana gelen her şey, Allah'in bir eylemi olarak ifade ediliyordu. Çocuklann, ay, güneş, sel, açlık, kıtlık, doğum, hastalik ve ölüm gibi tabî̀ felaket ve olaylan anlayabilmek için bu güçleri bilmeleri gerekiyordu. Yine çocuklarnn O'nu memnun edecek tarzda davranabilmesi için, O'nu tanımasına ihtiyaçları vardı. Genelde Allah korkusu teşvik edilir ve çocuklann davranışlanın kontrol vasıtası olarak kullanulırdı.

\footnotetext{
${ }^{33}$ David Heller, Talking to Your Orild A bout God, Bantam Books, Toronto, New York, 1988, 158. Aynca bkz. Mualla Selçuk, Coougìn Ë̈itioninde Din̂̀ Mocifler, Türkiye Diyanet Vakf, Yay., Ankara, 1990, 77; Hasan Dam, "ilkö̈rerim I: Kademe (4-5) Ö̈rnenileninin Din Hakkunda Sorduklan Sonular we Bu Sorular

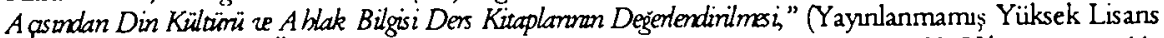
Tezi), Ondokuz Mayss Üniversitesi, Sosyal Bilimler Enstitüsü, Samsun, 1996, 88-89; Ylmaz, a.g.t., 6162.
} 
Allah'a inanç, bu kötü ve zorlu dünyada yaşamak zorunda kalan kişiler için bir güç kaynağıyd.

Elbette günümüzde de bu şekilde bir Allah inancı vermeye çalșan aile ve kişiler vardır. Ancak günümüzdeki çocuklan bu tür bir inançla ikna etmeye çalş̧mak gerçekten zordur. Zira duygu ve düşüncenin tüm modern versiyonu, bizim tecrübe ettiğimiz gerçeklere farklı bakmakta ve farkh yorumlamaktadır. Yukanda da değindiğimiz gibi, geçmişteki “her şey Allah'ın iradesi ve istemesiyle oluşur" şeklindeki önerme, günümüzde bu olaylarn birtakım çeşitli tabî̀ güçler yoluyla, ömeğin ekonomik, sosyal, siyasî, psikolojik ve fizyolojik nedenler sonucu ortaya çıktı̆ı savunulmaktadır. Bu anlayışın bir sonucu olarak artık biz, Allah'in Rezzak (nzk verici) sıfatı yerine, hayat sigortasi; hastalıklardan kurtulmak için dua yerine, ilaçlann önerildiği bir dünyada yaşıyor ve bu şekilde bir eğitim alıyoruz. Hastalıklann ve yağmur yağışının nedenleri de hep fizikî kanunlarla açıklanmaya çalışılmaktadır. Yine dünyanun sonuyla ilgili olarak da, bunun ilâhi bir müdahale yerine, insan yapımı bir hidrojen bombası ya da diğer ekolojik dengelerin bozulması sonucu olacağı öğretilmektedir. Tabi ki tüm bu bilimsel anlamdaki izah tarzlan, çocuklarda, hatta yetişkinler de bile tabiatüstü bir varlığa olan gerçek bir bağımlllk hissini azaltmaktadır. ${ }^{34}$ Durum böyle olunca, çocuklann sorduklan o dehşet ve zor sorulann bir çoğuna da yeterli cevap verilememektedir.

Tüm bu zorluklara rağmen, daha önce de değindiğimiz gibi, din eğitimcileri, çocuklara öğretilebilecek en temel ve en esash şeyin Allah kavramı olduğunu ileri sürmektedirler. Çocuklara doğru ve gerçekçi bir Allah kavramı öğretmeksizin, diğer dinî konularda bir şeyler öğretmeye kalkışmak, zaman israfından başka bir şey değildir. O yüzden de çocuklara önce doğru bir Allah kavramı öğretmemiz gerekmektedir.

Cinsiyet, kişilik, huy, karakter ve aile yapısı gibi çocuklanı dinî inanç öğretimine etki eden pek çok faktör olmasına rağmen, 35 en önemli etkenin yaş farklulğından kaynaklanmasından dolayı, yine kısaca çocuklann yaşla birlikte gösterdikleri özelikleri belirtip, bu yaş grubu çocuklara uygulanacak bazı prensiplerden bahsetmek istiyoruz.

4-6 yass arasi: Bazı psikologlara göre 4 yaş, çocuklann dinî alandaki ilgilerinin altın çağıdır. ${ }^{36}$ Çocuklar bu dönemde (4-6 yaş) Allah hakkında

\footnotetext{
${ }^{34}$ Edith F. Hunter, The Questioning Orild and Religion, The Starr King Press, Boston, 1956, 76-77.

${ }^{35}$ Heller, The Orildren's God, 39-93.

${ }^{36}$ Antoine Vergote, The Religiass Man: A Psyobdogical Santy of Religious A tritudes, trans. by Marie-Bemard Said, Pflaum Press, Dayton, OH, 1969, 276.
} 
düşünüp O'nun hakknnda konuşabilir ve bir Yaratıcı ile hayat olaylan arasında bazı temel iliskiler kurabilirler. Onlar dünyanın nasıl yaratıldığın ve Allah'n hali hazırdaki dünyaya ve dünya olaylanna olan etkisini ve rolünü tartş̧abilirler. Bu dönemdeki çocuklardan çoğu, Allah’ı basit ve sevecen bir şekilde tasvir ederken, sayılan az da olsa bazı çocuklar, din bağlaminda küresel sorunlara karşıı ömeğin, açlk ve savaş gibi konulara karşıı büyük ilgi duyabilirler. ${ }^{37}$

$\mathrm{Bu}$ dönemdeki çocuklarla, Allah ya da her hangi bir dinî konuda tartı̧̧ırken bu tartışmanın mantıkî olarak basit ve açık olması gerekir. Eğer tartı̧̧ma çok karmaşık ve zor olursa, çocuğun kafası karışıp, bu tür konularda tartışmaktan ve ilgi duymaktan vazgeçebilir. Bu küçük çocuklar için eylemyönlü stratejiler en bilgi verici ve faydahı olanıdır.

7.9 yas arasi: Bu yaşlar arasındaki çocuklar Allah hakkında daha fazla soyut düşünme özelliğine sahiptirler. Bu dönemdeki çocuklar, öncekilerinin aksine anne ve babalannun söyledikleri her şeyi lafzî olarak algulamazlar. Bunun anlam, bu dönem çocukları daha soyut düsünüp, görïlmeyen ve aşikâr olmayan varlkklar hakkunda düşünmeye hazır bir durumda olabilirler. Bu dönem, çocuklannun, Allah hakkında hem isteklerinin hem de korkularnnı olduğu bir dönemdir. Bu çocuklar çoğunlukla ailenin ve çevresinin sahip olduğu resmî dinin öğretilerini kabul ederler ve birtakım dinî soru, korku ve endişelere de sahip olabilirler. ${ }^{38}$

Bu dönem çocuklannda anne ve babanun, hikâyeler yoluyia iletişim kurmalan en iyi yollardan birisidir. Onlar hikâyelerdeki karakterleri kolay bir şekilde kişiselleştirebilir ve insanlann yaşamlanyla yakundan ilgilenebilirler. Dolaysıyla bu dönem çocuklanna, kutsal kitaplarda geçen hikâyeler anlatulabilir.

10-12 yas aras: Bu dönemdeki çocuklar önceki çocuklara oranla Allah ve etrafındaki dünya hakkında daha araştırmacı ve meraklıdurlar. Onlar daha fazla karmaşık konular hakkında konuşmaya ilgi duyarlar. Dinî konulardaki düsüücelerini ifade etmede daha az korku duyarlar. Zira onlar artuk şüphenin tabiî bir şey olduğunu öğrenmişlerdir. Bu dönem çocuklan da hâlâ Allah's insanî terimlerle tasvir edebilirler. Ancak Allah tasavvuru daha ruhânî bir özellik göstermektedir. Allah inancını ötesinde bu dönem çocuklan ahret hayatıyla da yakından ilgilenirler. ${ }^{39}$

\footnotetext{
${ }^{37}$ Heller, Talking to Your Orild A bout God, 49.

${ }^{38}$ Heller, Talking to Your Osild A bat God, 50.

${ }^{39}$ Heller, Talking to Your Child A bout God, 51.
} 
Bu özelliklerine bağh olarak bu dönem çocuklanna rahatllkla soyut kavramlardan bahsedilebilir. Artık onlar Allah'in sufatlann daha tam olarak algılayabilirler. İyi rehberlik yapıldığında birtakım dini pratikleri de kolaylıkla yapabilirler.

Çocukların dini inanç öğretimiyle ilgili bir diğer önemli soru da, bu eğitimin kim tarafından gerçekleştirileceği sorusudur. Aşağı yukarı tüm din eğitimcileri, özellikle bu ilk dönemdeki sorumluluğu aileye yüklemektedirler. ${ }^{40}$ Bu alanda yapılan pek çok araştırma, ailenin dini tutumların oluşmasında en karar verici bir faktör olduğunu ortaya koymaktadır. Çocuklarda dini tutumların oluşmasında aile faktöründen sonra bireysel düsünce ve okul gelmektedir.41 Aile çocuklann dini gelişimleri ve tutumlanna sadece ilk tesir etmekle kalmayp, bu durum daha sonraki ilişkilerin devamunda da belirleyici bir rol oynamaktadur. ${ }^{42}$

Bir Amerikalı din eğitimcisi olan James M. Lee, geleceğin din eğitiminin aile temelli olması gerektiğini belirterek özetle şunlan söylemektedir: Potansiyel olarak en kapsamlı ve en başanlı din eğitimi programı aile temelli din eğitimidir. Yaşam en derin ve kişisel seviyede aile içinde yaşanmaktadır. Hatta bu durum parçalanmıs ya da tek anne ve babadan oluşan aileler için bile geçerlidir. Psikolojilk veriler şunu ortaya koymaktadır ki, kişinin değer ve tutum yapısı ilk altı yaşında oluşmaktadır. Bu da büyük ölçüde aile içinde yaşanmaktadır. O bakımdan aile hayatı ve aile temelli din eğitimi, son derece önemli görülmektedir. ${ }^{43}$

Ailedeki din eğitimini verimli kllan etmenlerden biri de örgün eğitimde olduğu gibi her hangi bir zorlamanın olmayışıdır. Zira zorunlu devam, hangi ders için olursa olsun, özellikle de din eğitimi için bir engeldir. Zorunlu devam bireyleri dine çekmekten ziyade onlan dinden soğutmaktadır. Kişi bazında din işi biraz hür bir icraattur. Bu yüzden aile temelli gönüllü din eğitimi, örgün din eğitimdeki zorunlu din eğitiminden çok daha etkili ve faydalidur. ${ }^{44}$

Elbette aile her zaman çocuğun doğru ve sağllklı dini inançlara sahip olmasına neden olmayabilir. Sağlkł bir dini gelişim için pek çok ailevi

${ }^{40}$ Michacl Argyle, Religiows Behariour, The Free Press, Glencoe, Illinois, 1962, 40; Mehmet Emin Ay,

"Aile Ortaminda Yerine Getirilen Ibadetlerin Cocuk Üzerine Etkileri," Din Ë̈timi A rasttrmalan

Dergisi sayn 1, İstanbul, 1994, 163-164.

${ }^{41}$ Vergote, ag.e, 275.

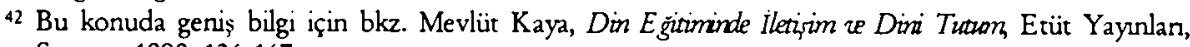
Samsun 1998, 136-167.

${ }^{43}$ Lee, ag.b., 115.

${ }^{44}$ Lee, a.g.b. 123. 
özelikler vardır. Ancak bunlar arasında sevgi ve güvenin tesisi gibi hiçbir gerekli ve yeterli fenomen yoktur. ${ }^{45}$ İster rutin konularda, ister inanç konulannda olsun sevgi, çocuk ebeveyn iliş̧kisinin özünü ve esasın oluşturmaktadır. Aile ortamında da manevi bir atmosfer oluşturulmak isteniyorsa, önce yapılacak iş, o ortamda sevgi unsurunu oluşturmak olmalıdır. Aile ortamindaki bireyler ne kadar dini konularda hassas olup, dini uygulamalara ne kadar önem verirlerse versinler, eğer sevgi yoksa, o ev ortamunda dini inançlar er geç sönmeye mahkumdur.

İşte Allah inancı konusunda çocuklara verilecek illk tema sevgi motifi olmalıdır. Çocuklara nasıl ki kendilerini her şeyden çok sevip, onlar için sayısız zorluk ve sıkıntılara katlanıyorsak, aynı şekilde Allah'in da bu anne ve baba sevgisine paralel hatta onlardan kat kat Allah'in kendilerini sevdiğini, bunun sonucu olarak da Allah'in bizlere çeşitli nimetler verdiğini, bizi hastalıklardan ve kötülüklerden koruduğunu bildirmemiz gerekir.

Pek çok anne-baba çocuklanna Allah hakkında bir şeyler vermek ve öğretmek isterler, ancak bunun nasıl olacağı konusunda fazla bir şey bilmezler. Ya geçiştirirler ya da çocuklannun Allah hakkunda sorduklan sorulan yersiz ve dini inançlara ters düsüyor diye bu tür sorular sormaktan men ederler, ya da hiç çocuğun gelişim seviyesini, ilgi ve alakasın hesaba katmadan geniş geniş açıklamaya çalışırlar ki, bu da öncekiler gibi sağlkklı bir dini bilgilendirmeden uzak bir durumdur. O halde ne yapılmalıdır?

Her şeyden önce bu konularda konuşabilmek için çocuklarnn yaşın dikkate almak gerekir. Psikologlara göre çocuklarla Allah ve diğer dini konularda konuşmanun en uygun yaşı 4 ve 5 yaşlardır. Bu da ancak çocuk tarafından bu gibi konulara bir ilgi ve merak duyulduğu an yapılmalıdır. $O$ halde çocuklan bu tür konulara teşvik etmek gerekir. Her ne kadar çocuklar dini konularda, özelliklede Allah hakkında konuşmak isteseler de, o çok soyut bir kavram olduğundan ve hakkında konuşmak zor olduğundan, bazı çocuklar Allah hakkında konuşmaktan çekinebilirler. İ̧̧e bu gibi durumlarda anne ve babalar bizzat çocuğu dini konularda konuşmaya teşvik etmelidir. ${ }^{46}$ Bu noktada çocuklara bu konunun niçin ve ne kadar önemli olduğu hatırlatılmalıdır. Çocuğa belki bizim Allah'ı ne kadar çok sevdiğimizi, bu yüzden kendisinin de bu konuda bir șeyler bilmesi gerektiğini söyleyebiliriz. Kendisinin de onun hakkında neler düşündüğünü öğrenmek isteyebiliriz. Çocuğa Allah'ın kendimiz için, ailemiz ve tüm insanllk için ne kadar önemli olduğunu anlatmaya çalı̧̧abiliriz. Yine bu bağlamda Allah'a yaptığımız

\footnotetext{
${ }^{45}$ Heller, The Gildren's God, 141.

${ }^{46}$ Heller, Talking to Your Orild A bout God, 47.
} 
ibadetin, caminin ve cemaatin önemini ve diğer ibadetlerin yaşamımızdaki yerini anlatabiliriz.

Diğer bir husus da, dinî inanç konulannun otorite aracllğıyla öğretilmesi yerine, onlann yaraticluk ve hayal güçlerinden yararlanmak suretiyle öğretilmeye ve tecrübe ettirilmeye çalş̧ılmasıdır. Şunu unutmamak gerekir ki, en kalıı ve sağlam öğrenme, ancak kişinin kendi çabalan sonucu gerçekleştirdiği ögrenme şeklidir.

Bu genel prensiplerin ötesinde, özellikle Allah inancıyla ilgili öğretim faaliyetlerinde ifadelerin, mümkün olduğunca kısa, öz, anlaml, sevgiye dayah, sade ve açık olmasına dikkat edilmelidir. Bu bağlamda, "Allah birdir, Allah yaratıcıdır, her şeye gücü yeter, $O$ tüm tabiattaki varlkkların nzkını verendir, O tüm sıfatlannda tamdır, $\mathrm{O}$ sonsuzdur, $\mathrm{O}$ güçlüdür, her şeyi bilir, her şeyi görür, her şeye gücü yeter. $O$ tüm yaratıklarn sever. Yalnuzca O'na ibadet edilir," şeklindeki ifadeler ömek olarak verilebilir. ${ }^{47}$

Kanaatimizce burada, anne ve babalara düsen görev, çocukların sonun ettikleri ya da gerçekten ilgi duydukları konulara odaklanmalandır. Eğer çocuğu gökyüzündeki yldızlar ve ay ilgilendirmiyor, onu büyülemiyorsa, ondan uzun uzadıya bahsetmenin hiçbir anlamı yoktur. Diğer taraftan, eğer o Allah'in neye benzediğini, hatta ne giyindiğiyle ilgileniyorsa, konuşmalann merkezinin bu konuların oluşturması gerekir. Ancak hiçbir zaman çocuğa "senin bu şekilde inandiğın yanliştur" diyerek, onun inançlanna engel olmamak gerekir. Diğer alanlarda olduğu gibi, dinî alanda da çocuğun sorulanyla ilgilenilmesi, onda daha sonraki yllarda sağlkklı bir dinî gelişim için son derece önemli ve gereklidir. Şunu unutmamak gerekir ki, çocuklara verilecek cevaplar, onlan ruhsal olarak rahatlatacağı gibi, kendi anlayıs seviyelerinin ötesinde verildiğinde, ruhsal sıkuntlara düşmesine de neden olabilir. 48

\section{Sonuf̧}

Diğer geliş̧im basamaklannda olduğu gibi, dini inanç gelişimi açısından da çocukluk döneminin kendisine has bazı özellikleri vardır. Bunlarn başında, çocuklarn kolay inanırlğıl, ben merkezci bir yönelimi, spontane bir dini

\footnotetext{
47 Bu konuda daha geniş bilgi için bkz. Mehmet Emin Ay, Çouklanmza A llab'z Našl A rlatalım Timaş Yaynlan, İstanbul, 1994, 109-132.

48 Hunter, age, 80. Aynca blzz. Osman Taştekin, Kryame we Abiretle Ilgili Kavrartarn Ögretim; Palmiye Yaynnlan, Samsun, 2002, 213, 223-226; Mualla Öztürk, "Din Egitimi ve Cocuk Ruh Sağlyğ1," Timkije 1. Din Eg̈itimi Semineri, 23-25 Nisan 1981, İlahiyat Vakf, Yayınlan, Ankara, 206-210; Aralay Yörükoğlu, "Ruh Sağlŭ̆l, Ahlak Değerleri ve Din Egitimi," Tïhkije 1. Din Eg̈itim Semineri 23-25 Nisan 1981, Ilahiyat Vakfi Yaynlan, Ankara, 211-214.
} 
tecrübe ile antropomofik bir Allah anlayışına sahip olma gibi özellikler gelmektedir.

Çocuklann dini eğitimine olumlu ya da olumsuz açıdan etki eden pek çok faktör vardır. Ancak bunlar arasında yaş, cinsiyet, kişilik ve karakter özellikleri ile aile yapısı ve tutumu çok daha önemli bir yere sahiptir. Tüm bu özellikler onlann Allah inancı ve tasavvuruna da etki etmektedir. Dolayssıyla çocukların dini eğitiminde, tüm bu farklı özellikler göz önüne alınarak, çağdaş eğitim ilkse ve prensipleri ışığında "kısa, öz, anlaml, sevgiye dayalı, sade ve açı" bir din eğitimi ve öğretimi verilmeye çalışlmalıdır. 